\title{
Strengthening marine amphipod DNA barcode libraries for environmental monitoring
}

Chinnamani Prasannakumar ${ }^{1,2^{*}}$, Ganesh Manikantan $^{3}$, J. Vijaylaxmi ${ }^{4}$, Balakrishnan Gunalan $^{3,5}$, Seerangan Manokaran ${ }^{6}$, S. R. Pugazhvendan ${ }^{7,8}$

${ }^{1}$ Biological Oceanography Division, CSIR-National Institute of Oceanography, Dona Paula, Panaji, Goa-403004, India.

${ }^{2}$ Institute of Marine Microbes and Ecosphere, State Key Laboratory for Marine Environmental Sciences, Xiamen University, Xiamen, Fujian, 361102, PR China.

${ }^{3}$ Centre of Advance studies in Marine Biology, Annamalai University, Parangipettai, Tamil Nadu- 608502, India.

${ }^{4}$ Department of Marine Sciences, Goa University, Taleigao Plateau, Goa-403206, India.

${ }^{5}$ Post Graduate and Research Department of Zoology, Thiru Kolanjiappar Government Arts College, Virudhachalam, Tamil Nadu- 606001, India.

${ }^{6}$ Center for Environment \& Water, King Fahd University of Petroleum and Minerals, Dhahran-31261, Saudi Arabia.

${ }^{7}$ Department of Zoology, Arignar Anna Government Arts College, Cheyyar, Tamil Nadu604407, India.

${ }^{8}$ Department of Zoology, Annamalai University, Annamalai Nagar, Chidambaram, Tamil Nadu- 608002, India.

*Corresponding author's email id: micropras@gmail.com

\begin{abstract}
Environmental DNA barcoding technology is gaining innovative applications. The effectiveness of current DNA barcode reference libraries in identifying amphipod barcodes and/or strengthening the existing library was tested. From 2500 amphipod individuals we barcoded 22 amphipod species belonging to 17 genera, 13 families among which 13 species were first time barcoded. More than 80 percent of the species were new distributional records. The minimum and maximum inter-specific pair-wise distance values was respectively 0.16 and 5.51 percent. Defining family specific species threshold values would be imperative, rather than expecting a universal barcode gap for amphipod species. The overall mean pair-wise distance, nucleotide diversity and Tajima's statistics were 3.59 percent, 0.27 and 2.62, respectively. There is a strong need to increase the number of
\end{abstract}


amphipod species barcodes in the reference database. For better facilitation of environmental monitoring, the datasets could be exclusively accessed at BOLD through http://dx.doi.org/10.5883/DS-MAOI.

Keywords: Marine amphipods; Environmental monitoring; COI; DNA barcoding; Amphipod barcoding.

\section{Introduction}

Amphipods (Phylum: Arthropoda, Class: Malacostraca, Order: Amphipoda) are a significant invertebrate fauna associated with coastal ocean environments which connects producers and consumers (such as fishes) in marine trophic webs (Sanchez-Jerez et al. 1999; Zakhama-Sraieb et al. 2006; Fernandez-Gonzalez and Sanchez-Jerez 2014). Amphipods have been used as key species in the assessment of environmental quality because they live in close proximity to marine and estuarine sediments (Chapman et al., 1992, Chapman et al., 2013, Postma et al., 2002) and are used as a bio-indicator of contamination since they are responsive to changes in environmental conditions (Bellan-Santini 1980; Virnstein 1987; Conradi et al. 1997; Guerra-Garcia and Garcia-Gomez 2001). Example; oil spills affects growth and abundance of amphipod fauna (Gesteira et al., 2000; Andrade \& Renaud, 2011; Joydas et al., 2012; Lotufo et al., 2016) and the bioaccumulation of hydrocarbons differs between families of amphipods (Lourenco et al., 2019). Amphipods are used to monitoring sediments acute toxicity which was proven to be species-specific (Ohji et al., 2002; Vacchi et al., 2019). Amphipods were also used to biomonitor the trace metal concentrations in coastal environments (Rainbow et al., 1998; Fialkowski et al., 2009; Morrison et al., 2017). By shredding plastic carrier bags, amphipod species were known to generate numerous pieces of microplastics which in turn significantly reduces amphipod's algal consumption (Hodgson et al., 2018; Carrasco et al., 2019). Changes in algal nutritional quality due to ocean acidification was also known to modify amphipod's feeding behavior (Benítez et al., 2016). Other environmental parameters such as light intensity and salinity influences the growth and the composition of amphipod assemblages (Navarro-Barranco \& Hughes, 2015; de-la-OssaCarretero et al., 2016). Therefore, the composition of the amphipod species typically represents the environmental conditions where they have been isolated.

Conventional taxonomy tussles to classify amphipods as they were small sized with poor taxonomic descriptions and converging morphological characters (Knowlton, 1993, Radulovici et al., 2010), making them an ideal group for DNA barcoding application. DNA 
barcoding involves sequencing a gene fragment from precisely identified specimens to form a database and enabling species identification (even by non-experts) by comparing the same gene sequences sequenced from unidentified specimens (Hebert et al., 2003, Mitchell, 2008). DNA barcode based identification was successful in marine amphipods of Arctic (Tempestini et al., 2018), Antarctic (Havermans et al., 2011), Atlantic (Costa et al., 2009) and Pacific (Jażdżewska and Mamos, 2019) Oceans. Such efforts, however are rare in Indian Ocean realms where amphipod diversity were relatively richer (Mondal et al., 2010, Raja et al., 2013).

Environmental DNA (eDNA) is the DNA recovered from environmental substances such as water, soil, or sediment (Taberlet et al. 2012; Thomsen and Willerslev 2015) and eDNA barcoding refers to sequencing the DNA barcodes, amplified from DNA recovered in the environmental for discovering the taxonomy and biodiversity of the sampled area. eDNA barcoding technology is finding innovative applications for monitoring marine biodiversity (Nguyen et al., 2020), from deep sea hydrothermal vents (Cowart et al., 2020) to plankton gut materials (Oh et al., 2020) and also in tracking terrestrial biodiversity (Heyde et al., 2020). eDNA barcoding technology has also been shown to be useful in monitoring the marine ecosystem to detect invasive species (Kim et al., 2020) even from the DNA recovered from marine litters (Ibabe et al., 2020).

eDNA technology has been shown to be useful in spatial and temporal monitoring in a wide variety of settings, as the methods are relatively inexpensive, reliable and quicker than conventional monitoring (Lecaudey et al. 2019; Preissler et al. 2019; Reinhardt et al. 2019; Sutter and Kinziger 2019; Sales et al. 2020). The breakthrough in eDNA barcoding technology is in its ability to monitor the ecosystem without causing unnecessary harm to ecosystem or their organisms by non-invasive sampling strategy (Antognazza et al. 2019; Mora et al. 2019; Leempoel et al. 2020) and to detect elusive, rare, and cryptic species effectively even in low density occurrences (Franklin et al. 2019; Shelton et al. 2019; Takahara et al. 2020). Single eDNA sampling could simultaneously monitor biodiversity in the given environment over a broad taxonomic spectrum (Sawaya et al. 2019; Thomsen and Sigsgaard 2019; Zhang et al. 2020). Large DNA barcode reference library that contains barcodes for a wide range of species is essential for successful monitoring of any environments using eDNA. For example; while monitoring marine ecosystems, a previous study could not assign more than 92 percent of the PCR amplified eDNA sequences to any known phyla and the sequences were classified as unassigned phyla (Jeunen et al., 2019; Sawaya et al., 2019). A comprehensive, parameterized reference library with barcodes of 
most of the locally occurring species and its image data is critical for the reliable application of eDNA technology, and the success of such efforts has been witnessed in probing marine fish diversity (Stoeckle et al., 2020). Barcode of Life Database (BOLD) (www.boldsystems.org) were created with the objective of fulfilling above said requirements (Ratnasingham and Hebert, 2007).

Since only 15 percent of animal species have been barcoded and available in reference libraries (Kvist, 2013), the purpose of this study is to classify amphipods that occur in Vellar estuary sediments using DNA barcoding. We have made considerable efforts in the past decade as part of the Indian Census of Marine Life (ICoML) to recover barcodes in reasonable numbers of marine phyla including fin and shell fishes, invertebrates (Khan et al., 2010, 2011; PrasannaKumar et al., 2012; Thirumaraiselvi et al., 2015; Rajthilak et al., 2015; Rahman et al., 2013, Hemalatha et al., 2016; Palanisamy et al., 2020; PrasannaKumar et al., 2020a, b; Manikantan et al., 2020; Thangaraj et al., 2020) and plants (Sahu et al., 2016; Prasanthi et al., 2020) occurring in and around the Vellar estuary, besides amphipods. This study also aims to test the efficacy of current DNA barcode reference libraries in identifying DNA barcodes, so as to implicitly explain the capacity of the reference library to monitoring environmental quality using eDNA barcodes of amphipods.

\section{Materials and methods}

\subsection{Sample collection and identification}

During February 2012, sediment samples were obtained from the mangroves beds in the Vellar estuary (Latitude: $11^{\circ} 29^{\prime}$ N. Longitude: $79^{\circ} 46^{\prime} E$.), Southeast coast of India. A total of 6 samples were sampled at multiple sites around the mangrove species; Rhizopora annamalayana (Seetharaman and Kandasamy, 2011) using a sterile plastic spatula within the sediment area of $50 \mathrm{~cm}^{2}$ quadrat. The seaward salinity was 30ppt (measured using hand-held Brix refractometer). The sediment samples were passed with copious ambient seawater through a sieve of $0.5 \mathrm{~mm}$ pore size and sewn at the site. The amphipods and other fauna were preserved in 95 percent molecular grade ethanol (Merck, India) along with residual sediments and transported to the laboratory. Whenever required, duplicate specimens were preserved for microscope analysis in 5 to 7 percent formaldehyde containing Rose Bengal. Using a Nikon Eclipse E200 compound microscope, the amphipods were sorted and classified to the lowest possible taxonomic ranking based on their morphological characters. For the identification of the specimens, the taxonomic keys of Vinogradov et al. (1996), Martin and Davis, (2001) Bousfield (1978), Balasubrahmaniyan and Srinivasan (1987), Lyla et al. (1999) and Lowry \& 
Myers (2017) which are publicly accessible via the World Amphipoda Database (Horton et al., 2019). Recommended data categories such as geographical co-ordinates, collector, and collection date, unique identifier for voucher specimens, etc., to meet basic data standards for creation of collection database (Evans \& Paulay, 2012) was followed. Under the project "DNA barcoding marine amphipods" (tag; DBMA), the barcode data along with image and other meta-data of the present study was released for publically access in BOLD (www.boldsystem.org).

\subsection{DNA isolation, $P C R$ and sequencing}

The DNA was extracted using the DNeasy Blood \& Tissue Kits (Qiagen) following the manufacturer's protocols with 1/10th of actual volume of reagents being adjusted in use. Two or three pereopods were used for DNA extraction, when the individual amphipods were $>12 \mathrm{~mm}$ in length, and the entire amphipod specimens when $<12 \mathrm{~mm}$ in length. During the DNA extraction process, elution buffer provided with the kit was used as negative control. Using the primer pair; LCO1490 and HCO2198 (Folmer et al., 1994), the mitochondrial cytochrome c oxidase subunit I (COI) gene was amplified (approximately, 658 base pair). Polymerase chain reaction (PCR) was conducted using a $25 \mu 1$ reaction volume; $12.5 \mu 1$ Taq PCR Master Mix (Invitrogen, India), $11 \mu 1$ distilled water, $0.5 \mu 1$ forward $(10 \mu \mathrm{M}) \& 0.5 \mu 1$ reverse primer $(10 \mu \mathrm{M})$, and $0.5 \mu 1$ extracted DNA (50-80 ng/ $\mu \mathrm{l})$. PCR conditions were; initial 2 minute denaturation at $95^{\circ} \mathrm{C}$, followed by 5 cycles at $94{ }^{\circ} \mathrm{C}$ at $30 \mathrm{~s}, 46^{\circ} \mathrm{C}$ at $45 \mathrm{~s}, 72$ ${ }^{\circ} \mathrm{C}$ at $45 \mathrm{~s}$ and 35 cycles at $94{ }^{\circ} \mathrm{C}$ at $30 \mathrm{~s}, 51^{\circ} \mathrm{C}$ at $45 \mathrm{~s}, 72{ }^{\circ} \mathrm{C}$ at $45 \mathrm{~s}$, and final elongation at 72 ${ }^{\circ} \mathrm{C}$ at 5 minutes. The negative control processed during DNA extraction used as a negative PCR control. Following PCR, the products were tested on a 1.5 percent agarose gel and commercially Sanger sequenced (bi-directionally) at Macrogen (Seoul, South Korea).

\subsection{DNA sequence analysis}

Sequencing efforts were repeated until at least one specimen in every species captured was sequenced. The sequences were read using ChromasLite ver.2.1 and manually double checked. DNA gaps were tested in BioEdit ver. 7.9 (Hall, 1999) by converting DNA sequences into putative amino acid sequences and aligned in Clustal $\mathrm{X}$ ver. 2.0.6 (Thompson, 1997). Properly aligned sequences were submitted to GenBank and made available for public access through accession numbers MT184213-MT184234. Under the project title "DNA Barcoding Marine Amphipods" or by using the tag 'DBMA' in BOLD (http://www.boldsystems.org/), meta-data containing voucher information, taxonomy, specimen description and collection data (sample ID, collection date, geographical 
information, etc.) could be accessed. One could access the dataset provided in the present study at http://dx.doi.org/10.5883/DS-MAOI.

The Barcode of Life Data Systems (BOLD) (Ratnasingham and Hebert, 2007) and GenBank (Benson et al., 2018) were used as a reference library to identify the barcode sequences created in the present study. The comparison of COI sequences in BOLD was facilitated through 'identification tool (http://www.boldsystems.org/index.php/IDS_OpenIdEngine) and in GenBank through Basic Local Alignment Searching Tool (BLAST) (Altschul et al., 1990) using a standard similarity search protocol (Hu and Kurgan, 2018). Molecular Evolutionary Genetic analysis (MEGA) version X (Kumar et al., 2018) was used for neighbour-joining (NJ) tree construction using Kimura 2 parameters (K2P). Calculations of the pair-wise distance were rendered using the K2P distance model (Kimura, 1980), nucleotide diversity and Tajima's statistical test (Tajima, 1989; Nei and Kumar, 2000) were carried out in MEGA X. All 3 codon positions were included in the analysis. For tree based identification, NJ tree was redrawn for better representation in Interactive Tree Of Life (iTOL) (Letunic and Bork, 2019).

\section{Result and discussion}

\subsection{Species composition and history of its occurrences}

We retrieved a total of 2869 amphipod individuals with intact morphometric characteristics. Morphological descriptions assigned the entire collection to 22 species (Fig. 1), 17 genera, and 13 families under the order Amphipoda. List of species described was given in table 1. The Isaeidae family contributed the maximum number of species $(n=3)$, followed by 2 species each in Ampeliscidae, Ampithoidae, Aoridae, Corophiidae, Gammaridae, Maeridae and Talitridae (Table S1). The families such as Deaxaminidae, Eriopisidae, Hyalidae, Melitidae and Photidae has contributed single species in the collection.

Folmer's primer (Folmer et al., 1994) effectively amplified all 22 species, eliminating the need for additional prime pairs such as those needed for barcoding Atlantic (Costa et al., 2009) and deep sea Pacific amphipods (Jażdżewska and Mamos, 2019). All sequences have been positively confirmed as fragments of the Amphipoda COI gene through BLAST searches. Of the 22 species barcoded in this study, only 4 species viz., Ampelisca scabripes (Walker, 1904), Grandidierella sp. (Coutière, 1904), Orchestia sp. (Leach, 1814) and Talorchestia sp. (Dana, 1852) was reported previously in Vellar estuary (Mondal et al., 2010). For the sampled area, more than 81 percent of the species were new records. Further investigation could be directed towards reasoning these new occurrences in Vellar mangrove 
environment. Hence we investigated previously recorded known habitats of these amphipod species, to perceive any recent notable environmental changes.

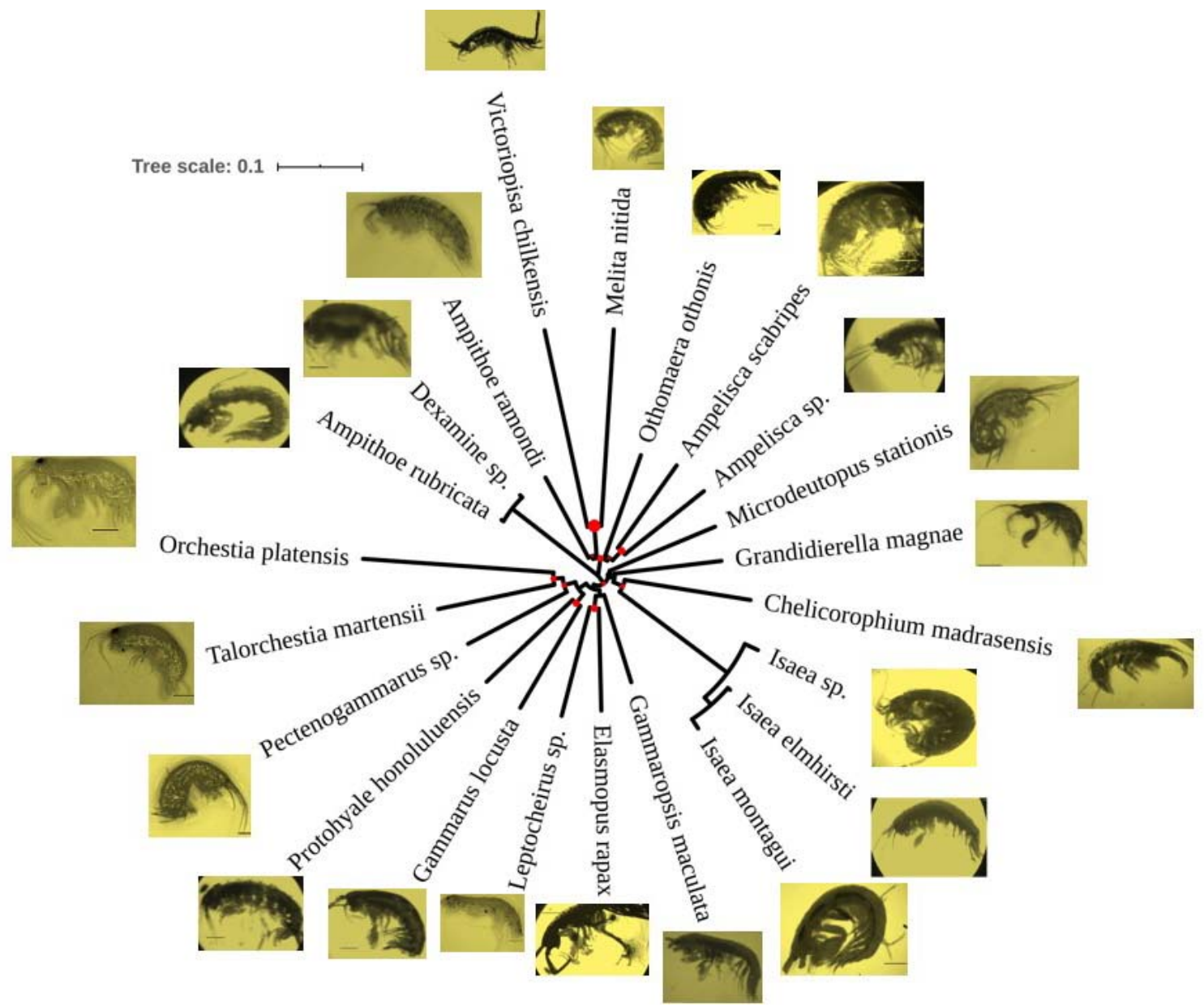

Fig. 1: Circular NJ tree drawn using Kimura-2 parametric distance model employing the COI sequences represented by each species of amphipods barcoded. The images represent the duplicate specimens used for image analysis.

Since 1975 (Rabindranath, 1975) till the date (Srinivas, 2019), Ampelisca scabripes (Walker, 1904) has been known to occur in Indian estuarine environment. While Ampithoe ramondi (Audouin, 1826) occurrences in South Pacific islands were recorded as early as 1986 (Myers, 1986) and their active feeding on leaves and seeds of seagrasses were well known (Castejón-Silvo et al., 2019), their occurrences in the present study are not surprising, given the presence of seagrass patches in Vellar estuary (Ranjitham et al., 2008). Ampithoe rubricata (Montagu, 1808) are the most common amphipods previously recorded in kelp forest habitats (Norderhaug et al., 2003), an active red algae feeders (Norderhaug, 2004). 
Chelicorophium madrasensis (Nayar, 1950) is the continuous feeder recently recorded to dominate amphipod composition of the Cochin estuary sediments along India's southwestern coast (Rehitha et al., 2019). They have also been recorded elsewhere as a common inhabitant of mangrove forests (Wongkamhaeng et al., 2015). The barcoded Elasmopus rapax (Costa, 1853) in this study was previously identf2ied from the coast of Venezuela (Zanders and Rojas, 1992) and its invasiveness is realized in Australian waters (Hughes and Lowry, 2010). Possible invasiveness of this species in mangrove surroundings in Vellar can warrant more investigations. The barcoded Gammaropsis maculata (Johnston, 1828 ) in this study is a good indicator of the complex hydrological forces in an ecosystem 2(Conradi, 2001) and is known to occur in the Tunisian coast of North Africa (ZakhamaSraieb, 2017). The currently barcoded Gammarus locusta (Linnaeus, 1758) was noted for its cosmopolitan estuarine distribution and is expected to be more resistant ocean acidifications (Hauton, 2009). Grandidierella megnae (Giles, 1890) barcoded in this study was previously known to occur along Iraq's Basrah coast (Naser et al., 2010) and on Thailand's Songkhla Lake (Rattanama et al., 2010). Isaea montagui (H. Milne Edwards, 1830) was noted for 2its epibiotic link to crabs (where the amphipod obtains its food from detritus and crab faeces) (Parapar, 1997).

The effectiveness of amphipod DNA barcodes in identifying invasive and delineating cryptic species has been well established (Witt et al., 2006; Bradford et al., 2010; Ros et al., 2015; Lipinskaya et al., 2018). Barcoded in the present study, Melita nitida (Smith, 1873) was confirmed to be an invasive species for the Western Scheldt estuary (in Netherlands) that was possibly transported by shipping (Faasse and van Moorsel, 2003). By forming irregular brood plate setae in their bodies (Borowsky et al., 1997), they were known bio-indicators of toxic and petroleum contaminants in sediments. Biomass of molluscan species of Vellar estuary were known to contain significant concentration of petroleum hydrocarbons (Veerasingam et al., 2011). Microdeutopus stationis (Della Valle, 1893) barcoded in this study is known to occur in the Tunisian coast of North Africa (Zakhama-Sraieb, 2017) and is abundantly reported in Isles of Scilly seagrass beds (Bowden, 2001).

Table 1: Identification of amphipod COI sequences using GenBank and BOLD databases 


\begin{tabular}{|c|c|c|c|c|c|}
\hline $\begin{array}{l}\text { Species identified in } \\
\text { the present study }\end{array}$ & $\begin{array}{l}\text { Closest species } \\
\text { match in } \\
\text { GenBank }\end{array}$ & $\begin{array}{l}\text { BLAST } \\
\text { similarity } \\
(\%)\end{array}$ & $\begin{array}{l}\text { Accession } \\
\text { numbers of } \\
\text { closest } \\
\text { match }\end{array}$ & BOLD best match & $\begin{array}{l}\text { Highest } \\
\text { similarity } \\
\text { in BOLD }\end{array}$ \\
\hline Ampelisca scabripes & $\begin{array}{l}\text { Ampelisca } \\
\text { macrocephala }\end{array}$ & 95.92 & MG313065 & No match & \\
\hline Ampelisca sp. & Ampelisca sp. & 98.21 & KX223977 & Ampelisca sp. & 100 \\
\hline Ampithoe ramondi & Ampithoe ramondi & 99.26 & KP316300 & Ampithoe ramondi & 100 \\
\hline Ampithoe rubricata & $\begin{array}{l}\text { Ampithoe } \\
\text { rubricata }\end{array}$ & 98.53 & HQ987379 & Ampithoe rubricata & 100 \\
\hline $\begin{array}{l}\text { Chelicorophium } \\
\text { madrasensis }\end{array}$ & $\begin{array}{l}\text { Chelicorophium } \\
\text { robustum }\end{array}$ & 93.11 & KM009063 & No match & \\
\hline Dexamine sp. & Dexamine thea & 97.89 & KT209114 & Dexamine sp. & 100 \\
\hline Elasmopus rapax & Elasmopus rapax & 98.69 & KX224028 & Elasmopus rapax & 100 \\
\hline $\begin{array}{l}\text { Gammaropsis } \\
\text { maculata }\end{array}$ & $\begin{array}{l}\text { Gammaropsis } \\
\text { maculata }\end{array}$ & 100 & MG935019 & $\begin{array}{l}\text { Gammaropsis } \\
\text { maculata }\end{array}$ & 100 \\
\hline Gammarus locusta & Gammarus locusta & 99.35 & MG935024 & Gammarus locusta & 100 \\
\hline $\begin{array}{l}\text { Grandidierella } \\
\text { megnae }\end{array}$ & $\begin{array}{l}\text { Grandidierella } \\
\text { chaohuensis }\end{array}$ & 92.82 & KT180187 & No match & \\
\hline Isaea elmhirsti & Dulichiidae sp. & 90.51 & MN346579 & No match & \\
\hline Isaea montagui & Dulichiidae sp. & 88.87 & MN346579 & No match & \\
\hline Isaea sp. & Dulichiidae sp. & 93.29 & MN346579 & No match & \\
\hline Leptocheirus sp. & $\begin{array}{l}\text { Leptocheirus } \\
\text { pinguis }\end{array}$ & 96.07 & MG318679 & Leptocheirus sp. & 100 \\
\hline Melita nitida & Melita nitida & 97.88 & KF273656 & Melita nitida & 97.35 \\
\hline $\begin{array}{l}\text { Microdeutopus } \\
\text { stationis }\end{array}$ & Microdeutopus sp. & 98.21 & KX224078 & $\begin{array}{l}\text { Microdeutopus } \\
\text { chelifer }\end{array}$ & 97.54 \\
\hline $\begin{array}{l}\text { Platorchestia } \\
\text { platensis }\end{array}$ & Platorchestia sp. & 93.63 & MH279725 & $\begin{array}{l}\text { Platorchestia } \\
\text { platensis }\end{array}$ & 100 \\
\hline Othomaera othonis & $\begin{array}{l}\text { Othomaera } \\
\text { othonis }\end{array}$ & 97.72 & MG935257 & No match & \\
\hline $\begin{array}{l}\text { Pectenogammarus } \\
\text { sp. }\end{array}$ & $\begin{array}{l}\text { Pectenogammarus } \\
\text { planicrurus }\end{array}$ & 92.21 & MK159963 & No match & \\
\hline $\begin{array}{l}\text { Protohyale } \\
\text { honoluluensis }\end{array}$ & $\begin{array}{l}\text { Protohyale cf. } \\
\text { jarrettae }\end{array}$ & 95.43 & MG319374 & No match & \\
\hline $\begin{array}{l}\text { Talorchestia } \\
\text { martensii }\end{array}$ & $\begin{array}{l}\text { Talorchestia } \\
\text { martensii }\end{array}$ & 98.85 & KC578515 & $\begin{array}{l}\text { Talorchestia } \\
\text { martensii }\end{array}$ & 100 \\
\hline $\begin{array}{l}\text { Victoriopisa } \\
\text { chilkensis }\end{array}$ & $\begin{array}{l}\text { Victoriopisa } \\
\text { chilkensis }\end{array}$ & 100 & MK526894 & No match & \\
\hline
\end{tabular}

Herbivorous nature of M. stationis may be the explanation for its preference of Vellar mangrove habitat. The barcoded Platorchestia platensis (Krøyer, 1845) was previously reported from the Swedish coast and the Baltic Sea (Persson, 2001). P. platensis's ability to reproduce in the warm temperature waters across the South African estuary was argued as one of its characteristics for its invasiveness (Hodgson et al., 2014). Othomaera othonis (H. 
Milne Edwards, 1830) barcoded in this study is known to occur in northern Atlantic Ocean in the Portuguese continental shelf (Sampaio et al., 2016) and in the Algerian, Mediterranean Sea continental shelf (Bakalem et al., 2020). However its occurrences in shallow mangrove sediments were unknown until now and requires further investigation. The barcoded Protohyale honoluluensis (Schellenberg, 1938) in this study was known to occur in the Hong Kong Island marine caves of (Horton, 2008).

The barcoded Talorchestia martensii (Weber, 1892) in this study is generally referred to as equatorial sandhoppers occurring in African beach sand (Ugolini, 2016) and Kenyan coast (Ugolini and Ciofini, 2015). T. martensii was widely used astronomical orientations researches (Ugolini and Ciofini, 2015; Ugolini, 2016). Victoriopisa chilkensis (Chilton, 1921) barcoded in the present study was known to occur on Malaysian coast (South China Sea) and was used as feed in Thailand's shrimp cultures (Yokoyma et al., 2002). Neither traditional nor molecular approaches could resolve the four taxa viz., Ampelisca sp., Dexamine sp., Isaea sp., Leptocheirus sp., and Pectenogammarus sp. recorded in this study to species level identification. In near future, these barcodes in the public databases may be resolved to species level when the respective barcodes of the species were obtained elsewhere.

\subsection{Sequence analysis and species identification}

The COI sequences represented by the families viz., Ampeliscidae [Ampelisca sp. (Krøyer, 1842), A. scabripes (Walker, 1904)], Corophiidae [Chelicorophium madrasensis (Nayar, 1950), Leptocheirus sp. (Zaddach, 1844)], Aoridae [Grandidierella megnae (Coutière, 1904)], Talitridae [Platorchestia platensis (Krøyer, 1845), Talorchestia martensii (Weber, 1892)), Hyalidae (Protohyale honoluluensis (Schellenberg, 1938)] and Isaeidae [Isaea sp. (H. Milne Edwards, 1830), I. elmhirsti (Patience, 1909) and I. montagui (H. Milne Edwards, 1830)] were barcoded for the first time (59\% of the sequences). Over $59 \%$ of the barcoded species in this study was missing in the reference libraries. The COI sequences of the Isaeidae family produced in the present study were found to be sequenced for the first time, because previously no COI barcodes of this family were found in the GenBank library. Even when the COI barcodes where referred across in the BOLD database, BOLD declared the first time barcoded species as "no match" in their database (Table 1). In general, significant amounts of barcode records were resolved up to family level in the reference database, partly because $90 \%$ of multicellular organisms remain undescribed (Kwong et al., 2012; Curry et al., 2018) and the Vellar estuary could be hot spot for marine fauna and flora 
yet to be barcoded (Khan et al., 2010; PrasannaKumar et al., 2020a, c; Manikantan et al., 2020; Prasanthi et al., 2020).

Since 18 species among the 22 barcoded species were not recognized to occur during previous study (Mondal et al., 2010), the development of this local barcode library would help in the near future to monitor amphipod species diversity and composition through eDNA barcoding surveys. As seen in few marine amphipod species of Canadian waters (Tempestini et al., 2018), we detected no stop codons in the COI sequences. Mean GC content was $39.25 \pm 0.93 \%$ which is slightly higher than the Arctic amphipod's GC content of $(32.9 \%)$ (Tempestini et al., 2018). Table 2 provides descriptive statistics for the distribution of nucleotide frequencies.

Of the 22 species barcoded, least inter-specific pair-wise distance of $0.16 \%$ was observed between Isaea elmhirsti and I. montagui (Table S2). The maximum inter-specific distance of $5.51 \%$ was observed between Victoriopisa chilkensis and Orchestia platensis (Table S2). The inter-specific maximum $(0.16 \%)$ and minimum $(5.51 \%)$ values observed were lower than what those reported in Canadian amphipods $(0.6 \%$ and $18.07 \%$, respectively) (Tempestini et al., 2018). The interspecific values observed for deep-sea amphipod species (13\%) (Knox et al., 2012) was also higher than the maximum interspecific values observed in this study. Although a $16 \%$ threshold has been suggested for the delineation of amphipod species (in Gammaridae or Niphargidae) (Lefébure et al., 2006; Flot et al., 2010; King et al., 2011; Fiser et al., 2015), lower values have also been recorded for Talitridae (8 - 17\%) (King et al., 2011) or for Hyalleidae (4\%) (Witt et al., 2008).

Table 2: Summary statistics for nucleotide frequency distribution.

\begin{tabular}{lllll}
\hline Nucleotide composition (\%) & Minimum & Mean & Maximum & Standard error \\
\hline Guanine (G) & 12.89 & 19.83 & 26.92 & 0.7789 \\
\hline Cytosine (C) & 14.19 & 19.69 & 26.1 & 0.5526 \\
\hline Adenine (A) & 21.21 & 25.46 & 31 & 0.5843 \\
\hline Thymidine (T) & 29.85 & 35.03 & 39.8 & 0.5434 \\
\hline GC (all codon positions) & 31.65 & 39.52 & 46.82 & 0.9315 \\
\hline GC-Codon Position 1 & 37.25 & 45.83 & 51.96 & 0.8605 \\
\hline GC-Codon Position 2 & 39.02 & 42.22 & 43.9 & 0.302 \\
\hline GC-Codon Position 3 & 13.24 & 30.48 & 45.59 & 2.0274
\end{tabular}

When we averaged the pairwise distance of each species to the rest of the species barcoded in this study, we found Melita nitida and Victoriopisa chilkensis had the maximum pairwise average distance (0.45) (Fig. 2). By including COI sequences from 13 families, we 
show that the threshold of $16 \%$ was too high to delineating most of the species barcoded in this study and proposed inter-specific values of $26.8 \%$ for Gammaridae species (Costa et al., 2009) was more than 4 times the maximum inter-specific values observed among the species in this study. Similar observations were also reported in Canadian amphipods (Tempestini et al., 2018). The interspecific divergence among the species of Gammarus genera was found to be more than $20 \%$ (Hou et al., 2009).

Hence, it is becoming clearer that each amphipod family have differential species threshold as genetic variability among amohipods depends on family traits such as habitat preferences and geological history (Knox et al., 2020). At the same time family traits alone cannot be reasoned, as there exists a contrasting genetic structure even among closely related amphipod species (Baird et al., 2011). Hence defining family specific species threshold for delineating amphipod species is necessary.

The overall average pair-wise distance was 3.59\%. Nucleotide diversity and Tajima's statistics were 0.27 and 2.62 , respectively. We found that $34.86 \%$ were conservative sites and $58.2 \%$ was parsimonious from the final alignment.

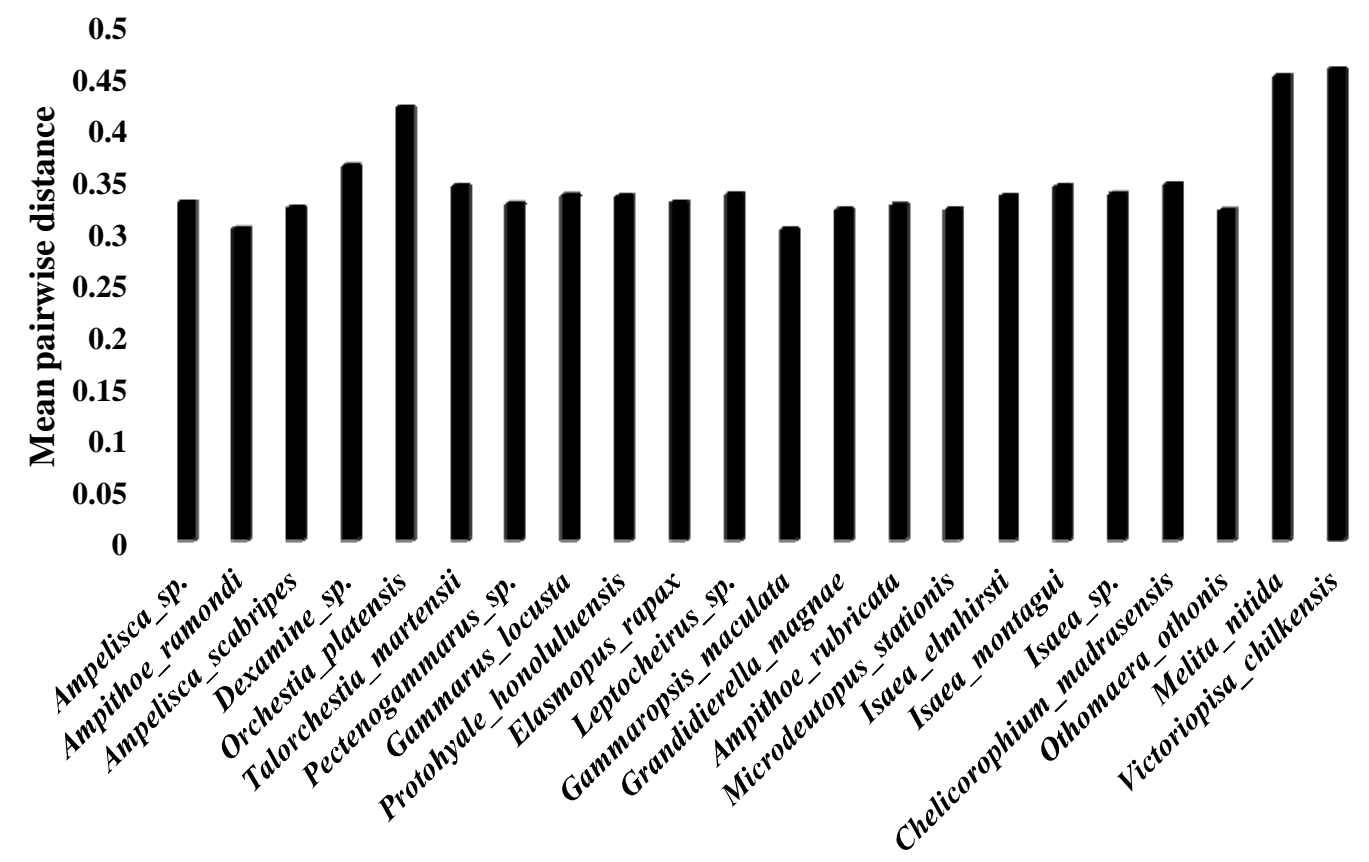

Amphipod species

Fig. 2: Average pair-wise distance between each species versus rest of the amphipod species barcoded.

Though the percentage of conservative sites were slightly higher than Canadian amphipods $(23.5 \%)$, percentage of parsimonious sites were slightly lower when compared to 
Canadian amphipods (69.25\%) (Tempestini et al., 2018). Using a single gene for species identification may introduce bias in different steps of sample processing (Radulovici et al., 2010), lack of established barcode gap (Meier et al., 2008), and superficial increase in species threshold estimates by 'COI-like' sequences (Buhay, 2009). Hence we also conducted treebased species identification using clustering analysis.

\subsection{Tree based identification}

Based on the statistical significance (percentage of identity, query coverage, e-value), reference sequences for tree based identifications were retrieved from GenBank. Details of all sequences obtained during BLAST analysis was listed in Table S3. The first time sequenced species which did not had significant match in the database were used as such in the construction of the NJ tree without any reference sequence (Fig. 2). All COI sequences generated in this study $(n=22)$, clustered with the reference sequences $(n=24)$ of respective species in the same branch (Fig. 3). Most of the branches (>90\%) in the NJ tree were backed by maximum (>75) bootstrap values. The references sequences precisely clustered with its corresponding species barcoded in this study, suggesting the success of tree based identification. The NJ tree constructed using COI sequences generated 3 major clades (Fig. 3). A minor clade consisting of two genera (M. nitida and $V$. chilkensis) was the first and top most clade in the tree. There are 3 genera (Ampithoe, Ampelisca and Othomaera) in the second and middle clade.

The largest clade consisting of 14 genera was the bottom-most and the third clade. 3 subclades were evident within the third clade, where the genera Dexamine constituted the smallest sub-clade. The second sub-clade contained the members of Ampithoidae, Aoridae, Corophiidae, Isaeidae and Photidae. The bottom-most and third sub-clade contained the members of Corophiidae, Gammaridae, Hyalidae, Maeridae and Talitridae. While certain members of the same family (example; Gammaridae, Corophiidae) or the same genera (example; Ampithoe) did not cluster together, sequences of same taxa cluster together suggest the efficacy of COI sequences in species delineation. There was also evidence that the members of the same family (example, Isaeidae) forming single cluster. 




Fig. 3: NJ tree was drawn using COI sequences with Kimura-2 parametric distance model. The sequences retrieved from GenBank were represented by "accession-number_speciesname". Example; "MG935024_Gammarus locusta". The sequences of the present study were represented with species name only. Time scale and bootstrap legends were given at the top left corner of the tree. More than $90 \%$ of the branches were supported by $>75 \%$ of bootstraps values. 


\subsection{Environmental monitoring}

Amphipods are commonly used to assess sediment quality in marine and estuarine environments (Chapman 1992, 2013; Postma et al., 2002). High throughput sequencing has enabled the identification of array of species present in the environment by means of its eDNA presence in the environmental substances (Cristescu, 2014; Deiner et al., 2014; Braukmann et al., 2019). This eDNA barcoding approach reveals species composition of entire trophic levels, from complex bulk environmental samples, gut or faeces content in soil and in aquatic environments or from ancient samples collected within permafrost or in sediments (Cristescu, 2014; Deiner et al., 2017). Thus the composition of amphipod species revealed by such approach will in turn disclose the environmental quality (polluted, nonpolluted, toxic compounds, etc.). The eDNA barcoding begins by collecting a large number of sequences from one or more standard barcode region targeting a specific groups or taxa (Hebert et al., 2018), followed by comparing these sequences with the reference sequences in the databases like GenBank and BOLD.

More species coverage in the reference database is strongly required, as the sequencing costs of next generation sequencing are reducing (Hebert et al., 2003; Shokralla et al., 2014; Cruaud et al., 2017) and sequences from museum and type specimens could be obtained (Prosser et al., 2016). Since 59\% of the species barcoded in this study were first time sequenced and released for public access, the present data set will aid to improve species coverage in the databases and encourage better monitoring of the environment. The reliability of environmental and meta-DNA barcoding studies depends on validated reference library generated through taxonomic expertise, accessible image data, voucher specimens and their genetic materials. The dataset developed through this study has been made available in both GanBank and BOLD. For the present study dataset, a unique digital object identifier has been created in BOLD, which can be accessed at http://dx.doi.org/10.5883/DS-MAOI. The voucher specimens were accessible through the Centre Advanced Study in Marine Biology, Annamalai University's Marine Museum, which will allow future referencing analysis or avoid identification error cascades (Bortolus, 2008). Cryopreserved genetic materials were also accessible upon request, as we realised the values of such materials in construction of reference library (Hanner and Gregory, 2007; Gonzalez et al., 2018). 


\section{Conclusion}

We show that, reference libraries (GenBank and BOLD) have to be strengthened for improved barcode based amphipod species identification, as small sequencing effort such as ours discovered 13 species as first time barcoded. While our data set represents local custom library for the identification of amphipod species with limited taxonomic reach $(n=22$ species), with meta-data ready for accession, they have become less prone to errors (Machida et al., 2017; Heller et al., 2018). The current study provides a valuable reference library particularly for those species that were first time barcoded, against which barcodes of marine amphipods from different regions can be referred in the near future, as these parameterized reference libraries will be crucial to species identification (Ekram et al., 2007; Wilson et al., 2011). Since amphipods are widely used as a universal taxonomic screening tool in environmental monitoring, amphipod barcodes along geographic and ecological data, may not only promote our knowledge on taxonomy, phylogeography, and species crypticism, but also serve as a powerful tool for environmental monitoring and health assessment. It should be noted that the DNA barcoding technology is growing beyond systematic or taxonomic study. At the same time, the developing high-throughput sequencing technologies massively alters environmental surveys and bio-monitoring applications (Fonseca et al., 2010; Hajibabaei et al., 2011; Leray et al., 2015). As a result, reference datasets such as ours will become important for health assessment and environmental monitoring using amphipod barcodes. Although the creation of a comprehensive amphipod barcode library with extensive species coverage was an ultimate goal (example; Zahiri et al., 2017) this study represents a small step towards it.

\section{Acknowledgement}

First author thanks the INSPIRE Fellowship of the Department of Science and Technology (IF10431), India and China Postdoctoral Research Foundation (0050-K83008), China for their financial assistance. We thank Raja $\mathrm{S}$ for his assistance with the taxonomic knowledge and the verification of species. We acknowledge Ms. Clare Adams, Department of Anatomy, Dunedin, New Zealand's efforts for critically reviewing the manuscript and improving its content. We thank the anonymous reviewers for improving the quality of the manuscript. 


\section{References}

Altschul, S.F., Gish, W., Miller, W., Myers, E.W. \& Lipman, D.J. (1990) "Basic local alignment search tool." J. Mol. Biol. 215:403-410.

Andrade, H., \& Renaud, P. E. (2011). Polychaete/amphipod ratio as an indicator of environmental impact related to offshore oil and gas production along the Norwegian continental shelf. Marine Pollution Bulletin, 62(12), 2836-2844. https://doi.org/10.1016/j.marpolbul.2011.08.032

Antognazza CM, Britton JR, Potter C, Franklin E, Hardouin EA, Gutmann Roberts C et al (2019) Environmental DNA as a non-invasive sampling tool to detect the spawning distribution of European anadromous shads (Alosa spp.). Aquat Conserv Mar Freshw Ecosys 29:148-152.

Baird, H.P., Miller, K.J., Stark, J.S., 2011. Evidence of hidden biodiversity, ongoing speciation and diverse patterns of genetic structure in giant Antarctic amphipods. Mol Ecol 20 .

Bakalem, A., Hassam, N., Oulmi, Y., Martinez, M., \& Dauvin, J.-C. (2020). Diversity and geographical distribution of soft-bottom macrobenthos in the bay of Bou Ismail (Algeria, Mediterranean Sea). Regional Studies in Marine Science, 33, 100938. https://doi.org/10.1016/j.rsma.2019.100938

Balasubrahmaniyan, K., \& Srinivasan, M. (1987). Fouling organisms on oysters in Paravanar estuary. In Proceedings of the national seminar on estuarine management (pp. 511-513).

Barnes, M. A. \& Turner, C. R. The ecology of environmental DNA and implications for conservation genetics. Conserv. Genet. 17, 1-17 (2016).

Bellan-Santini D (1980) Relationship between populations of amphipods and pollution. Mar Poll Bull 11:224-227

Benítez, S., Duarte, C., López, J., Manríquez, P. H., Navarro, J. M., Bonta, C. C., Torres, R., \& Quijón, P. A. (2016). Ontogenetic variability in the feeding behavior of a marine amphipod in response to ocean acidification. Marine Pollution Bulletin, 112(1-2), 375-379. https://doi.org/10.1016/j.marpolbul.2016.07.016

Benson DA, Cavanaugh M, Clark K, Karsch-Mizrachi I, Ostell J, Pruitt KD, Sayers EW (2018) GenBank. Nucleic Acids Res. 2018 Jan 4; 46(D1):D41-D47.

Lourenço R. A., Magalhães C. A., Taniguchi S., Siqueira S. G. L., Jacobucci G. B., Leite F. P. P., Bícego M. C., (2019) Evaluation of macroalgae and amphipods as bioindicators of 
petroleum hydrocarbons input into the marine environment, Marine Pollution Bulletin, 145, 564-568. https://doi.org/10.1016/j.marpolbul.2019.05.052

Borowsky, B., Aitken-Ander, P., \& Tanacredi, J. T. (1997). Changes in reproductive morphology and physiology observed in the amphipod crustacean, Melita nitida Smith, maintained in the laboratory on polluted estuarine sediments. Journal of Experimental Marine Biology and Ecology, 214(1-2), 85-95. https://doi.org/10.1016/s0022-0981(96)02764-5

Bortolus, A. (2008) Error cascades in the biological sciences: The unwanted consequences of using bad taxonomy in ecology. Ambio 37, 114-118.

Bousfield, E. L. (1978). A revised classification and phylogeny of amphipod crustaceans. Transactions of Royal Society of Canada Series, 4, 343-390.

Bowden, D. A., Rowden, A. A., \& Attrill, M. J. (2001). Effect of patch size and in-patch location on the infaunal macroinvertebrate assemblages of Zostera marina seagrass beds. Journal of Experimental Marine Biology and Ecology, 259(2), 133-154. https://doi.org/10.1016/s0022-0981(01)00236-2

Bradford, T., Adams, M., Humphreys, W. F., Austin, A. D., \& Cooper, S. J. B. (2010). DNA barcoding of stygofauna uncovers cryptic amphipod diversity in a calcrete aquifer in Western Australiaâ $\square \mathrm{TM}_{\mathrm{S}}$ arid zone. Molecular Ecology Resources, 10(1), 41-50. https://doi.org/10.1111/j.1755-0998.2009.02706.x

Braukmann, T. W. A. et al. (2019) Metabarcoding a diverse arthropod mock community. Mol. Ecol. Res. 19, 711-727.

Buhay JE. (2009) "COI-like" sequences are becoming problematic in molecular systematic and DNA barcoding studies. J Crustacean Biol. 29(1): 96-110.

Carrasco, A., Pulgar, J., Quintanilla-Ahumada, D., Perez-Venegas, D., Quijón, P. A., \& Duarte, C. (2019). The influence of microplastics pollution on the feeding behavior of a prominent sandy beach amphipod, Orchestoidea tuberculata (Nicolet, 1849). Marine Pollution Bulletin, 145, 23-27. https://doi.org/10.1016/j.marpolbul.2019.05.018

Castejón-Silvo, I., Jaume, D., \& Terrados, J. (2019). Feeding preferences of amphipod crustaceans Ampithoe ramondi and Gammarella fucicola for Posidonia oceanica seeds and leaves. Scientia Marina, 83(4), 349. https://doi.org/10.3989/scimar.04892.06b

Chapman, P., Swartz, R., Roddie, B., Phelps, H., van den Hurk, P., Butler, R., 1992. An international comparison of sediment toxicity tests in the North Sea. Mar. Ecol. Prog. Ser. 91, 253-264, http://dx.doi.org/10.3354/meps091253. 
Chapman, P.M., Wang, F., Caeiro, S.S. (2013) Assessing and managing sediment contamination in transitional waters. Environ. Int. 55, 71-91, http://dx.doi.org/10.1016/j.envint.2013.02.009.

Conradi M, Lopez-Gonzalez PJ, Garcia-Gomez JC (1997) The amphipod community as a bioindicator in Algeciras Bay (Southern Iberian Peninsula) based on a spatio-temporal distribution. Mar Ecol 18(2):97-111, http://dx.doi.org/10.1111/j.1439-0485.1997.tb00430.x

Conradi, M. (2001). Relationships between environmental variables and the abundance of peracarid fauna in Algeciras bay (Southern Iberian Peninsula). Ciencias Marinas, 27(4), 481500. https://doi.org/10.7773/cm.v27i4.504

Costa, F. O., Henzler, C. M., Lunt, D. H., Whiteley, N. M., \& Rock, J. (2009). Probing marine Gammarus (Amphipoda) taxonomy with DNA barcodes. Systematics and Biodiversity, 7(4), 365-379. https://doi.org/10.1017/s1477200009990120

Cowart, D. A., Matabos, M., Brandt, M. I., Marticorena, J., \& Sarrazin, J. (2020). Exploring Environmental DNA (eDNA) to Assess Biodiversity of Hard Substratum Faunal Communities on the Lucky Strike Vent Field (Mid-Atlantic Ridge) and Investigate Recolonization Dynamics After an Induced Disturbance. Frontiers in Marine Science, 6. https://doi.org/10.3389/fmars.2019.00783

Cristescu, M. E. (2014) From barcoding single individuals to metabarcoding biological communities. Trends Ecol. Evol. 29, 566-571.

Cruaud, P., Rasplus, J.-Y., Rodriguez, L. J. \& Cruaud, A. (2017) High-throughput sequencing of multiple amplicons for barcoding and integrative taxonomy. Sci. Rep. 7, 41948.

Curry, C. J., Gibson, J. F., Shokralla, S., Hajibabaei, M. \& Baird, D. J. (2018) Identifying North American freshwater invertebrates using DNA barcodes: are existing COI sequence libraries fit for purpose? Freshwater Sci. 37, 178-189.

Deiner, K. et al. (2017) Environmental DNA metabarcoding: Transforming how we survey animal and plant communities. Mol. Ecol. 26, 5872-5895.

de-la-Ossa-Carretero, J. A., Del-Pilar-Ruso, Y., Loya-Fernández, A., Ferrero-Vicente, L. M., Marco-Méndez, C., Martinez-Garcia, E., Giménez-Casalduero, F., \& Sánchez-Lizaso, J. L. (2016). Bioindicators as metrics for environmental monitoring of desalination plant discharges. Marine Pollution Bulletin, 103(1-2), 313-318. https://doi.org/10.1016/j.marpolbul.2015.12.023

Ekrem, T., Willassen, E. \& Stur, E. A. (2007) Comprehensive DNA sequence library is essential for identification with DNA barcodes. Mol. Phylogenet. Evol. 43, 530-542. 
Evans, N., \& Paulay, G. (2012). DNA Barcoding Methods for Invertebrates. Methods in Molecular Biology, 47-77. https://doi.org/10.1007/978-1-61779-591-6 4

Faasse, M., van Moorsel, G. The North-American amphipods, Melita nitida Smith, 1873 and Incisocalliope aestuarius (Watling and Maurer, 1973) (Crustacea: Amphipoda: Gammaridea), introduced to the Western Scheldt estuary (The Netherlands). Aquatic Ecology 37, 13-22 (2003). https://doi.org/10.1023/A:1022120729031

Fernandez-Gonzalez J, Sanchez-Jerez P (2014) First occurrence of Caprella scaura Templeton, 1836 (Crustacea: Amphipoda) on off-coast fish farm cages in the Mediterranean Sea. Helgol Mar Res 68:187-191, https://doi.org/10.1007/s10152-013-0375-y

Fialkowski, W., Calosi, P., Dahlke, S., Dietrich, A., Moore, P. G., Olenin, S., Persson, L. E., Smith, B. D., Špegys, M., \& Rainbow, P. S. (2009). The sandhopper Talitrus saltator (Crustacea: Amphipoda) as a biomonitor of trace metal bioavailabilities in European coastal waters. Marine Pollution Bulletin, 58(1), 34-44. https://doi.org/10.1016/j.marpolbul.2008.09.013

Fišer Ž, Altermatt F, Zakšek V, Knapič T, Fišer C. (2015) Morphologically cryptic amphipod species are "ecological clones" at regional but not at local scale: a case study of four Niphargus species. PloS ONE. 10(7): e0134384.

Flot JF, Wörheide G, Dattagupta S. (2010) Unsuspected diversity of Niphargus amphipods in the chemoautotrophic cave ecosystem of Frasassi, central Italy. BMC Evol Biol. 10(1): 171.

Folmer O, Hoeh W, Black M, Vrijenhoek R. Conserved primers for PCR amplification of mitochondrial DNA from different invertebrate phyla. Mol Mar Biol Biotechnol. 1994; 3:294-299.

Fonseca, V. G., Carvalho, G. R., Sung, W., Johnson, H. F., Power, D. M., Neill, S. P., ... Creer, S. (2010). Second-generation environmental sequencing unmasks marine metazoan biodiversity. Nature Communications, 1(1). https://doi.org/10.1038/ncomms1095

Franklin TW, McKelvey KS, Golding JD, Mason DH, Dysthe JC, Pilgrim KL et al (2019) Using environmental DNA methods to improve winter surveys for rare carnivores: DNA from snow and improved non-invasive techniques. Biol Cons 229:50-58.

Gesteira, J. L. G., \& Dauvin, J.-C. (2000). Amphipods are Good Bioindicators of the Impact of Oil Spills on Soft-Bottom Macrobenthic Communities. Marine Pollution Bulletin, 40(11), 1017-1027. https://doi.org/10.1016/s0025-326x(00)00046-1

González, V. L. et al. (2018) Open access genomic resources for terrestrial arthropods. Curr. Opin. Insect Sci. 25, 91-98. 
Guerra-Garcia JM, Garcia-Gomez JC (2001) The spatial distribution of Caprellidea (Crustacea: Amphipoda): a stress bioindicator in Ceuta (North Africa, Gibraltar area). Mar Ecol PSZN 22:357-367

Hajibabaei, M., Shokralla, S., Zhou, X., Singer, G. A. C., \& Baird, D. J. (2011). Environmental Barcoding: A Next-Generation Sequencing Approach for Biomonitoring Applications Using River Benthos. PLoS ONE, 6(4), e17497. https://doi.org/10.1371/journal.pone.0017497

Hall, T.A. 1999. BioEdit: a user-friendly biological sequence alignment editor and analysis program for Windows 95/98/NT. Nucl. Acids. Symp. Ser. 41:95-98.

Hanner, R. H. \& Gregory, T. R. (2007) Genomic diversity research and the role of biorepositories. Cell Preserv. Technol. 5, 93-103.

Hauton C, Tyrrell T. and Williams J (2009) The subtle effects of sea water acidification on the amphipod Gammarus locusta. 6, 1479-1489.

Havermans, C., Nagy, Z. T., Sonet, G., De Broyer, C., \& Martin, P. (2011). DNA barcoding reveals new insights into the diversity of Antarctic species of Orchomene sensu lato (Crustacea: Amphipoda: Lysianassoidea). Deep Sea Research Part II: Topical Studies in Oceanography, 58(1-2), 230-241. https://doi.org/10.1016/j.dsr2.2010.09.028

Hebert, P. D. N. et al. (2018) A Sequel to Sanger: Amplicon sequencing that scales. BMC Genomics 19, 14.

Hebert, P. D. N., Cywinska, A., Ball, S. L. \& deWaard, J. R. (2003) Biological identifications through DNA barcodes. Proc. R. Soc. London Ser. B 270, 313-321.

Heller, P., Casaletto, J., Ruiz, G. \& Geller, J. B. (2018) A database of metazoan cytochrome c oxidase subunit I gene sequences derived from GenBank with CO-ARBitrator. Sci. Data 5, 180156.

Hemalatha, A., Mohammed Esa, S. A. R., Suresh, M., Thajuddin, N., \& Anantharaman, P. (2016). Identification of Odontella aurita by $\mathrm{rbcL}$ gene sequence - a high antibacterial potential centric marine diatom. Mitochondrial DNA Part A, 28(5), 655-661. https://doi.org/10.3109/24701394.2016.1166222

Heyde, M., Bunce, M., Wardell $\square$ Johnson, G., Fernandes, K., White, N. E., \& Nevill, P. (2020). Testing multiple substrates for terrestrial biodiversity monitoring using environmental DNA metabarcoding. Molecular Ecology Resources, 20(3). https://doi.org/10.1111/1755$\underline{0998.13148}$

Hodgson, A. N., Booth, A. J., David-Engelbrecht, V., \& Henninger, T. O. (2014). Some lifehistory parameters of the non-native amphipodPlatorchestia platensis(Talitridae) in a warm 
temperate South African estuary. Transactions of the Royal Society of South Africa, 69(2), 97-106. https://doi.org/10.1080/0035919x.2014.941961

Hodgson, D. J., Bréchon, A. L., \& Thompson, R. C. (2018). Ingestion and fragmentation of plastic carrier bags by the amphipod Orchestia gammarellus: Effects of plastic type and fouling load. Marine Pollution Bulletin, 127, 154-159. https://doi.org/10.1016/j.marpolbul.2017.11.057

Horton, T. (2008). Amphipoda from marine caves of Hong Kong Island. Journal of Natural History, 42(9-12), 825-854. https://doi.org/10.1080/00222930701860124

Horton, T., Lowry, J., De Broyer, C., Bellan-Santini, D., Coleman, C. O., et al., (2019). World Amphipoda Database.<http://www.marinespecies.org/amphipoda>(accessed on 201902-07).

Hou, Z., Li, Z., \& Li, S. (2009). Identifying Chinese species of Gammarus (Crustacea: Amphipoda) using DNA barcoding. Current Zoology, 55(2), 158-164. https://doi.org/10.1093/czoolo/55.2.158

Hu, G., \& Kurgan, L. (2018). Sequence Similarity Searching. Current Protocols in Protein Science, 95(1), e71. https://doi.org/10.1002/cpps.71

Hughes, L. E., \& Lowry, J. K. (2010). Establishing a Neotype for Elasmopus rapax Costa, 1853 and Its Presence as an Invasive Species in Temperate Australian Waters. Journal of Crustacean Biology, 30(4), 699-709. https://doi.org/10.1651/10-3290.1

Ibabe, A., Rayón, F., Martinez, J. L., \& Garcia-Vazquez, E. (2020). Environmental DNA from plastic and textile marine litter detects exotic and nuisance species nearby ports. PLOS ONE, 15(6), e0228811. https://doi.org/10.1371/journal.pone.0228811

Jażdżewska, A. M., \& Mamos, T. (2019). High species richness of Northwest Pacific deepsea amphipods revealed through DNA barcoding. Progress in Oceanography, 178, 102184. https://doi.org/10.1016/j.pocean.2019.102184

Jeunen, G., Knapp, M., Spencer, H. G., Lamare, M. D., Taylor, H. R., Stat, M., ... Gemmell, N. J. (2019). Environmental DNA (eDNA) metabarcoding reveals strong discrimination among diverse marine habitats connected by water movement. Molecular Ecology Resources, 19(2), 426-438. https://doi.org/10.1111/1755-0998.12982

Ji, Y. et al. (2013) Reliable, verifiable and efficient monitoring of biodiversity via metabarcoding. Ecol. Lett. 16, 1245-125.

Joydas, T. V., Qurban, M. A., Al-Suwailem, A., Krishnakumar, P. K., Nazeer, Z., \& Cali, N. A. (2012). Macrobenthic community structure in the northern Saudi waters of the Gulf, 
14years after the 1991 oil spill. Marine Pollution Bulletin, 64(2), 325-335. https://doi.org/10.1016/j.marpolbul.2011.11.007

Khan, S. A., Lyla, P. S., John, B. A., Kuamr, C. P., Murugan, S., \& Jalal, K. C. A. (2010). DNA Barcoding of Stolephorus indicus, Stolephorus commersonnii and Terapon jarbua of Parangipettai Coastal Waters. Biotechnology (Faisalabad), 9(3), 373-377. https://doi.org/10.3923/biotech.2010.373.377

Khan, S. A., Prasannakumar C, Lyla P. S., Murugan S (2011) Identifying Marine fin fishes using DNA barcodes. Current Science, vol. 101 (9): 1152-1154.

Kim, P., Yoon, T. J., \& Shin, S. (2020). Environmental DNA and Specific Primers for Detecting the Invasive Species Ectopleura crocea (Hydrozoa: Anthoathecata) in Seawater Samples. Sustainability, 12(6), 2360. https://doi.org/10.3390/su12062360

Kimura M. (1980). A simple method for estimating evolutionary rate of base substitutions through comparative studies of nucleotide sequences. Journal of Molecular Evolution 16:111120.

King RA, Leys R. (2011) The Australian freshwater amphipods Austrochiltonia australis and Austrochiltonia subtenuis (Amphipoda: Talitroidea: Chiltoniidae) confirmed and two new cryptic Tasmanian species revealed using a combined molecular and morphological approach. Invertebr Syst. 25(3): 171-196.

Knowlton N. Sibling Species in the Sea. Annu Rev Ecol Syst. 1993; 24(1):189-216.

Knox, M. A., Hogg, I. D., Pilditch, C. A., Lörz, A.-N., Hebert, P. D. N., \& Steinke, D. (2012). Mitochondrial DNA (COI) analyses reveal that amphipod diversity is associated with environmental heterogeneity in deep-sea habitats. Molecular Ecology, 21(19), 4885-4897. https://doi.org/10.1111/j.1365-294x.2012.05729.x

Knox, M.A., Hogg, I.D., Pilditch, C.A., Garcia-R, J.C., Hebert, P.D.N., Steinke, D., (2020) Contrasting patterns of genetic differentiation among amphipod taxa along New Zealand's continental margins, Deep-Sea Research Part I, doi: https://doi.org/10.1016/j.dsr.2020.103323

Kumar S, Stecher G, Li M, Knyaz C, and Tamura K (2018) MEGA X: Molecular Evolutionary Genetics Analysis across computing platforms. Molecular Biology and Evolution 35:1547-1549.

Kvist, S. (2013) Barcoding in the dark? A critical view of the sufficiency of zoological DNA barcoding databases and a plea for broader integration of taxonomic knowledge. Mol. Phylogenet. Evol. 69, 39-45. 
Kwong, S., Srivathsan, A. \& Meier, R. (2012) An update on DNA barcoding: low species coverage and numerous unidentified sequences. Cladistics 28, 639-644.

Lecaudey LA, Schletterer M, Kuzovlev VV, Hahn C, Weiss SJ (2019) Fish diversity assessment in the headwaters of the Volga River using environmental DNA metabarcoding. Aquat Conserv 29(10):1785-1800

Leempoel K, Hebert T, Hadly EA (2020) A comparison of eDNA to camera trapping for assessment of terrestrial mammal diversity. Proc Royal Soc B Biol Sci 287:20192353.

Lefébure T, Douady CJ, Gouy M, Gibert J. (2006) Relationship between morphological taxonomy and molecular divergence within Crustacea: Proposal of a molecular threshold to help species delimitation. Mol Phylogenet Evol. 40(2):435-447.

Leray, M., \& Knowlton, N. (2015). DNA barcoding and metabarcoding of standardized samples reveal patterns of marine benthic diversity. Proceedings of the National Academy of Sciences, 112(7), 2076-2081. https://doi.org/10.1073/pnas.1424997112

Letunic I and Bork P (2006). Interactive Tree Of Life (iTOL): an online tool for phylogenetic tree display and annotation. Bioinformatics 23(1):127-8

Lim J.H.C., Azam, B.A.R., Othman B.H.R. (2010) Melitoid amhipods of the genera Ceradocus Costa, 1853 and Victoriopisa Karaman and Barnard, 1979 (Crustacea: Amphipoda: Maeridae) from the South China Sea, Malaysia. 30, 23-39.

Lipinskaya, T., Radulovici, A., \& Makaranka, A. (2018). First DNA barcoding based record of Echinogammarus trichiatus (Martynov, 1932) (Crustacea, Gammaridae) in Belarus. BioInvasions Records, 7(1), 55-60. https://doi.org/10.3391/bir.2018.7.1.08

Lotufo, G. R., Farrar, J. D., Biedenbach, J. M., Laird, J. G., Krasnec, M. O., Lay, C., Morris, J. M., \& Gielazyn, M. L. (2016). Effects of sediment amended with Deepwater Horizon incident slick oil on the infaunal amphipod Leptocheirus plumulosus. Marine Pollution Bulletin, 109(1), 253-258. https://doi.org/10.1016/j.marpolbul.2016.05.073

Lowry, J.K., Myers, A.A., 2017. A phylogeny and classification of the Amphipoda with the establishment of the new order Ingolfiellida (Crustacea: Peracarida). Zootaxa. https://doi.org/10.11646/zootaxa.4265.1.1

Lyla, P. S., Velvizhi, S., \& Ajmal Khan, S. (1999). List of amphipods in Parangipettai coast (Southeast coast of India). Monograph series, UGC-Special Assistance Programme, CAS in Marine Biology, Annamalai University, Parangipettai (India), 38 pp.

Machida, R. J., Leray, M., Ho, S.-L. \& Knowlton, N. (2017) Metazoan mitochondrial gene sequence reference datasets for taxonomic assignment of environmental samples. Sci. Data 4, 170027. 
Manikantan, G., PrasannaKumar, C., Vijaylaxmi, J., Pugazhvendan, S. R., \& Prasanthi, N. (2020). Diversity, phylogeny, and DNA barcoding of brachyuran crabs in artificially created mangrove environments. Cold Spring Harbor Laboratory. https://doi.org/10.1101/2020.09.07.286823

Martin JW, Davis GE. An updated classification of the recent Crustacea. Sci Series, 2001; 39: $1-124$.

Meier R, Zhang G, Ali F. (2008) The Use of Mean Instead of Smallest Interspecific Distances Exaggerates the Size of the "Barcoding Gap" and Leads to Misidentification. Syst Biol. 57(5):809-813.

Mitchell, A. (2008) DNA barcoding demystified. Australian Journal of Entomology 47, 169173, https://doi.org/10.1111/j.1440-6055.2008.00645

Mondal, N., Rajkumar, M., Sun, J., Kundu, S., Lyla, P. S., Ajmal Khan, S., \& Trilles, J. P. (2010). Biodiversity of brackish water amphipods (crustacean) in two estuaries, southeast coast of India. Environmental Monitoring and Assessment, 171(1-4), 471-486. https://doi.org/10.1007/s10661-009-1292-Z

Mora AJ, Prosse SWJ, Mora JA (2019) DNA metabarcoding allows non-invasive identification of arthropod prey provisioned to nestling Rufous hummingbirds (Selasphorus rufus). Peerj 7:e6596.

Morrison, L., Bennion, M., McGrory, E., Hurley, W., \& Johnson, M. P. (2017). Talitrus saltator as a biomonitor: An assessment of trace element contamination on an urban coastline gradient. Marine Pollution Bulletin, 120(1-2), 232-238. https://doi.org/10.1016/j.marpolbul.2017.05.019

Myers, A. A. (1986). Amphipoda from the South Pacific: Niue Island. Journal of Natural History, 20(6), 1381-1392. https://doi.org/10.1080/00222938600770921

Naser, M., Ali, M., \& White, K. (2010). Grandidierella macronyx Barnard, 1935 (Amphipoda, Aoridae): a new record from Shatt Al-Basrah, Basrah, Iraq. Crustaceana, 83(11), 1401-1407. https://doi.org/10.1163/001121610x533511

Navarro-Barranco, C., \& Hughes, L. E. (2015). Effects of light pollution on the emergent fauna of shallow marine ecosystems: Amphipods as a case study. Marine Pollution Bulletin, 94(1-2), 235-240. https://doi.org/10.1016/j.marpolbul.2015.02.023

Nei M. and Kumar S. (2000). Molecular Evolution and Phylogenetics. Oxford University Press, New York. 
Nguyen, B.N., Shen, E.W., Seemann, J. et al. Environmental DNA survey captures patterns of fish and invertebrate diversity across a tropical seascape. Sci Rep 10, 6729 (2020). https://doi.org/10.1038/s41598-020-63565-9

Norderhaug, K., Fredriksen, S., \& Nygaard, K. (2003). Trophic importance of Laminaria hyperborea to kelp forest consumers and the importance of bacterial degradation to food quality. Marine Ecology Progress Series, 255, 135-144. https://doi.org/10.3354/meps255135

Norderhaug, K.M. (2004) Use of red algae as hosts by kelp-associated amphipods. Marine Biology 144, 225-230. https://doi.org/10.1007/s00227-003-1192-7

Oh, H.-J., Krogh, P. H., Jeong, H.-G., Joo, G.-J., Kwak, I.-S., Hwang, S.-J., Gim, J.-S., Chang, K.-H., \& Jo, H. (2020). Pretreatment Method for DNA Barcoding to Analyze Gut Contents of Rotifers. Applied Sciences, 10(3), 1064. https://doi.org/10.3390/app10031064

Ohji, M., Takeuchi, I., Takahashi, S., Tanabe, S., \& Miyazaki, N. (2002). Differences in the acute toxicities of tributyltin between the Caprellidea and the Gammaridea (Crustacea: Amphipoda). Marine Pollution Bulletin, 44(1), 16-24. https://doi.org/10.1016/s0025$\underline{326 x(01) 00146-1}$

Palanisamy, S. K., PrasannaKumar, C.*, Paramasivam, P., \& Sundaresan, U. (2020). DNA barcoding of horn snail Telescopium telescopium (Linnaeus C, 1758) using mt-COI gene

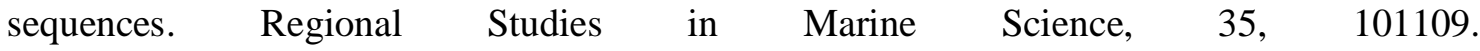
https://doi.org/10.1016/j.rsma.2020.101109

Parapar, J., Fernández, L., González-Gurriarán, E. \& Muiño, R. 1997. Epibiosis and masking material in the spider crab Maja squinado (Decapoda: Majidae) in the Ría de Arousa (Galicia, NW Spain). Cahiers de Biologie Marine, 38(4):221-234

Persson, L.-E. (2001). Dispersal of Platorchestia platensis (Kröyer) (Amphipoda: Talitridae) along Swedish coasts: A Slow but Successful Process. Estuarine, Coastal and Shelf Science, 52(2), 201-210. https://doi.org/10.1006/ecss.2000.0735

Postma, J.F., De Valk, S., Dubbeldam, M., Maas, J.L., Tonkes, M., Schipper, C.A., Kater, B.J. (2002). Confounding factors in bioassays with freshwater and marine organisms. Ecotoxicol. Environ. Saf. 53, 226-237, http://dx.doi.org/10.1006/eesa.2002.2195

PrasannaKumar C, Akbar John B, Ajmal Khan S, Lyla P S, and Jalal K C A (2012) Limit of DNA Barcode in Delineating Penaeus Monodon and in its Developing Stages. Sains Malaysiana 41(12): 1527-1533.

PrasannaKumar, C., Rethinavelu, S., \& Balamurugan, S. (2020a). First barcodes of Bathynomus kensleyi (Lowry \& Dempsey, 2006) and Bathynomus decemspinosus (Shih, 
1972) from the Southeast coast of India. Regional Studies in Marine Science, 101489. https://doi.org/10.1016/j.rsma.2020.101489

Prasannakumar, C., Iyyapparajanarasimapallavan, G., Rahman M. A. U., Mohanchander, P., Sudhakar, T. (2020b) Variability in the diet diversity of catfish highlighted through DNA barcoding. Cold Spring Harbor Laboratory. https://doi.org/10.1101/2020.09.18.268888

PrasannaKumar, C., Velmurugan, S., Subramanian, K., Pugazhvendan, S. R., Nagaraj, D. S., Khan, K. F., Sadiappan, B., Manokaran, S., Hemalatha, K. R., Sivamaruthi, B. S., \& Chaiyasut, C. (2020c). DNA barcoding analysis of more than 1000 marine yeast isolates reveals previously unrecorded species. Cold Spring Harbor Laboratory. https://doi.org/10.1101/2020.08.29.273490

Prasanthi, N., Prasannakumar, C., Annadurai, D., \& Mahendran, S. (2020). Identifying seaweeds species of Chlorophyta, Ochrophyta and Rhodophyta using DNA barcodes. Cold Spring Harbor Laboratory. https://doi.org/10.1101/2020.08.30.274456

Preissler K, Watzal AD, Vences M, Steinfartz S (2019) Detection of elusive fire salamander larvae (Salamandra salamandra) in streams via environmental DNA. Amphibia-Reptilia 40:55-64

Prosser, S. W. J., deWaard, J. R., Miller, S. E. \& Hebert, P. D. N. (2016) DNA barcodes from century-old type specimens using nextgeneration sequencing. Mol. Ecol. Resour. 16, 487497.

Rabindranath, P. (1975). Marine Gammaridea (Crustacea: Amphipoda) from the Indian region; family- Ampeliscidae. Hydrobiologia, 46(2-3), 241-262. https://doi.org/10.1007/bf00043143

Radulovici AE, Archambault P, Dufresne F. (2010) DNA Barcodes for Marine Biodiversity: Moving Fast Forward? Diversity. 2(4):450-72.

Rahman A M, Khan S A, Lyla P S, PrasannaKumar C (2013) DNA Barcoding Resolves Taxonomic Ambiguity in Mugilidae of Parangipettai Waters (Southeast Coast of India). Turkish Journal of Fisheries and Aquatic Sciences 13: 321-330.

Rainbow, P. S., Fialkowski, W., \& Smith, B. D. (1998). The sandhopper Talitrus saltator as a trace metal biomonitor in the Gulf of Gdansk, Poland. Marine Pollution Bulletin, 36(3), 193200. https://doi.org/10.1016/s0025-326x(98)00161-1

Raja, S., Lyla, P. S., \& Khan, S. A. (2013). Diversity of amphipods in the continental shelf sediments of southeast coast of India. Journal of the Marine Biological Association of India, 55(1), 35-41. https://doi.org/10.6024/jmbai.2013.55.1.01742.06 
Rajthilak, C., Santhanam, P., Raja, M., Suman, T. Y., Rajasree, S. R. R., Ramkumar, R., \& Perumal, P. (2015). First distributional record of Nitokra affinis Gurney, 1927 (Copepoda: Harpacticoida: Ameiridae) from Vellar estuary (south-east India): structural and molecular evidence. Marine Biodiversity Records, 8. https://doi.org/10.1017/s1755267215000391

Ranjitham NS, Thirumaran G, Anantharaman P, Nightingale DR and Balasubramanian R (2008). Associated fauna of seaweeds and seagrasses in Vellar estuary. American-Eurasian Journal of Botany. 1(1):9-16.

Ratnasingham, S., \& Hebert, P. D. N. (2007). Barcoding: BOLD: The Barcode of Life Data System (http://www.barcodinglife.org). Molecular Ecology Notes, 7(3), 355-364. https://doi.org/10.1111/j.1471-8286.2007.01678.x

Rattanama, K., Pattaratumrong, M. S., Towatana, P., \& Wongkamhaeng, K. (2016). Three New Records of Gammarid Amphipod in Songkhla Lake, Thailand. Tropical Life Sciences Research, 27(3), 53-61. https://doi.org/10.21315/t1sr2016.27.3.8

Rehitha, T.V., Madhu, N.V., Vineetha, G. et al. Macrobenthic fauna with special reference to the ecology and population structure of a tubicolous amphipod, Chelicorophium madrasensis (Nayar, 1950) in a tropical estuary, southwest coast of India. Mar Biodiv 49, 1013-1026 (2019). https://doi.org/10.1007/s12526-018-0886-5

Reinhardt T, van Schingen M, Windisch HS, Nguyen TQ, Ziegler T, Fink P (2019) Monitoring a loss: Detection of the semi-aquatic crocodile lizard (Shinisaurus crocodilurus) in inaccessible habitats via environmental DNA. Aquat Conserv 29:353-360

Ros, M., Vázquez-Luis, M., \& Guerra-García, J. M. (2015). Environmental factors modulating the extent of impact in coastal invasions: The case of a widespread invasive caprellid (Crustacea: Amphipoda) in the Iberian Peninsula. Marine Pollution Bulletin, 98(12), 247-258. https://doi.org/10.1016/j.marpolbul.2015.06.041

Rym Zakhama-Sraieb, Intissar Mnasser, Imen Zribi \& Faouzia Charfi-Cheikhrouha (2017) Update of checklist of marine Amphipoda in Tunisia from 2009 to April 2017. Biodiversity Journal, 8 (2): 493-496

Sahu, S. K., Singh, R., \& Kathiresan, K. (2016). Multi-gene phylogenetic analysis reveals the multiple origin and evolution of mangrove physiological traits through exaptation. Estuarine, Coastal and Shelf Science, 183, 41-51. https://doi.org/10.1016/j.ecss.2016.10.021

Sales NG, Wangensteen OS, Carvalho DC, Deiner K, Præbel K, Coscia I et al (2020) Spacetime dynamics in monitoring neotropical fish communities using eDNA metabarcoding. BioRxiv. https://doi.org/10. 1101/2020.02.04.933366 
Sampaio, L., Mamede, R., Ricardo, F., Magalhães, L., Rocha, H., Martins, R., Dauvin, J.-C., Rodrigues, A. M., \& Quintino, V. (2016). Soft-sediment crustacean diversity and distribution along the Portuguese continental shelf. Journal of Marine Systems, 163, 43-60. https://doi.org/10.1016/j.jmarsys.2016.06.011

Sanchez-Jerez P, Barberà-Cebriàn C, Ramos-Espla AA (1999) Comparison of the epifauna spatial distribution in Posidonia oceanica, Cymodocea nodosa and unvegetated bottoms: importance of meadow edges. Acta Oecolog 20: 391-405. https://doi.org/10.1016/S1146$\underline{609 X(99) 00128-9}$

Sansom BJ, Sassoubre LM (2017) Environmental DNA (eDNA) shedding and decay rates to model freshwater mussel eDNA transport in a river. Environ Sci Technol 51:14244-14253

Sawaya, N. A., Djurhuus, A., Closek, C. J., Hepner, M., Olesin, E., Visser, L., ... Breitbart, M. (2019). Assessing eukaryotic biodiversity in the Florida Keys National Marine Sanctuary through environmental DNA metabarcoding. Ecology and Evolution, 9(3), 1029-1040. https://doi.org/10.1002/ece3.4742

Seetharaman, K., \& Kandasamy, K. (2011). Reproductive biology of a natural mangrove hybrid Rhizophora annamalayana and its parent species (R. apiculata and R. mucronata) (Rhizophoraceae). Botanica Marina, 54(6). https://doi.org/10.1515/bot.2011.062

Shelton AO, Kelly RP, O’Donnell JL, Park L, Schwenke P, Greene C et al (2019) Environmental DNA provides quantitative estimates of a threatened salmon species. Biol Conserv 237:383-391.

Shokralla, S. et al. (2014) Next-generation DNA barcoding: Using next-generation sequencing to enhance and accelerate DNA barcode capture from single specimens. Mol. Ecol. Resour. 14, 892-901.

Srinivas, T., Sukumaran, S., Mulik, J., \& Dias, H. Q. (2019). Community structure of benthic amphipods in four estuaries of northwest India. Regional Studies in Marine Science, 27, 100532. https://doi.org/10.1016/j.rsma.2019.100532

Stoeckle, M. Y., Das Mishu, M., \& Charlop-Powers, Z. (2020). Improved Environmental DNA Reference Library Detects Overlooked Marine Fishes in New Jersey, United States. Frontiers in Marine Science, 7. https://doi.org/10.3389/fmars.2020.00226

Sutter M, Kinziger AP (2019) Rangewide tidewater goby occupancy survey using environmental DNA. Conserv Genet 20:597-613

Taberlet, P. et al. (2012a) Soil sampling and isolation of extracellular DNA from large amount of starting material suitable for metabarcoding studies. Mol. Ecol. 21, 1816-2. 
Taberlet, P., Coissac, E., Hajibabaei, M. \& Rieseberg, L. H. (2012b) Environmental DNA. Mol. Ecol. 21, 1789-93.

Tajima F. (1989). Statistical methods to test for nucleotide mutation hypothesis by DNA polymorphism. Genetics 123:585-595.

Takahara T, Minamoto T, Yamanaka H, Doi H, Kawabata Z (2012) Estimation of fish biomass using environmental DNA. PLoS ONE 7:e35868

Tempestini, A., Rysgaard, S., \& Dufresne, F. (2018). Species identification and connectivity of marine amphipods in Canada's three oceans. PLOS ONE, 13(5), e0197174. https://doi.org/10.1371/journal.pone.0197174

Thangaraj M, Annadurai D, Ramesh T, Kumaran R \& Ravitchandirane V (2020) DNA barcoding and preliminary phylogenetic analysis of few gastropods (Family: Potamididae and Nassariidae) in Vellar estuary mangroves, India by COI and 18S rRNA genes. Ind. J of Geo. Mar. Sci. 49(4): 596-600.

Thirumaraiselvi, R., Das, S., Ramanadevi, V., \& Thangaraj, M. (2015). MtDNA Barcode Identification of Finfish Larvae from Vellar Estuary, Tamilnadu, India. Notulae Scientia Biologicae, 7(1). https://doi.org/10.15835/nsb.7.1.9478

Thompson,J.D., Gibson,T.J., Plewniak,F., Jeanmougin,F. and Higgins,D.G. (1997) The ClustalX windows interface: flexible strategies for multiple sequence alignment aided by quality analysis tools. Nucleic Acids Research, 25:4876-4882.

Thomsen PF, Willerslev E (2015) Environmental DNA-an emerging tool in conservation for monitoring past and present biodiversity. Biol Conserv 183:4-18.

Ugolini, A. The moon orientation of the equatorial sandhopper Talorchestia martensii Weber. Behav Ecol Sociobiol 70, 1699-1706 (2016). https://doi.org/10.1007/s00265-016-2175-2

Ugolini, A., \& Ciofini, A. (2015). Landscape vision and zonal orientation in the Equatorial sandhopper Talorchestia martensii. Journal of Comparative Physiology A, 202(1), 1-6. https://doi.org/10.1007/s00359-015-1047-y

Vacchi, F. I., Santos, A. dos, Artal, M. C., Magalhães, G. R., Vendemiatti, J. A. de S., \& Umbuzeiro, G. de A. (2019). Parhyale hawaiensis as a promising alternative organism for monitoring acute toxicity of sediments under the influence of submarine outfalls. Marine Pollution Bulletin, 149, 110658. https://doi.org/10.1016/j.marpolbul.2019.110658

Veerasingam, S., Venkatachalapathy, R., Sudhakar, S., Raja, P., \& Rajeswari, V. (2011). Petroleum hydrocarbon concentrations in eight mollusc species along Tamilnadu coast, Bay of Bengal, India. Journal of Environmental Sciences, 23(7), 1129-1134. https://doi.org/10.1016/s1001-0742(10)60524-4 
Vinogradov ME, Causey D, Semenova TN, Volko AF. Hyperiid amphipods (Amphipoda, Hyperiidea) of the world oceans. Smithsonian Institution, Washington, DC. 1996

Virnstein RW (1987) Seagrass-associated invertebrate communities of the southeastern USA: a review. Fla Mar Res Publs 42:89-116

Wilson, J. J. et al. (2011) When species matches are unavailable are DNA barcodes correctly assigned to higher taxa? An assessment using sphingid moths. BMC Ecol. 11, 18.

Witt JD, Threloff DL, Hebert PDN. (2008). Genetic zoogeography of the Hyalella azteca species complex in the Great Basin: rapid rates of molecular diversification in desert springs. Geol Soc Spec Pap, 439: 103.

Witt, J. D. S., Threloff, D. L., \& Hebert, P. D. N. (2006). DNA barcoding reveals extraordinary cryptic diversity in an amphipod genus: implications for desert spring conservation. Molecular Ecology, 15(10), 3073-3082. https://doi.org/10.1111/j.1365294x.2006.02999.x

Wongkamhaeng, K., Nabhitabhata, J., \& Towatana, P. (2015). Corophiine amphipods of the genera Chelicorophium and Paracorophium from the lower Gulf of Thailand (Crustacea, Amphipoda, Corophiidae, Corophiinae). ZooKeys, 505, 35-50. https://doi.org/10.3897/zookeys.505.9751

Yokoyma, H., Higano, J., Adachi, K., Ishiht, Y., \& Yamada, Y. (2002). Evaluation of shrimp polyculture system in Thailand based on stable carbon and nitrogen isotope ratios. Fisheries Science, 68(4), 745-750. https://doi.org/10.1046/j.1444-2906.2002.00488.x

Zahiri, R. et al. (2017) Probing planetary biodiversity with DNA barcodes: The Noctuoidea of North America. PLoS ONE 12, e0178548.

Zakhama-Sraieb R, Sghaier YR, Charfi-Cheikhrouha F (2006) Is amphipod diversity related to the quality of Posidonia oceanica beds? Biol Mar Medit 13:174-180

Zanders, I.P., Rojas, W.E. Cadmium accumulation, LC50 and oxygen consumption in the tropical marine amphipod Elasmopus rapax. Marine Biology 113, 409-413 (1992). https://doi.org/10.1007/BF00349166

Zhang Y, Pavlovska M, Stoica E, Prekrasna I, Yang J, Slobodnik J et al (2020) Holistic pelagic biodiversity monitoring of the Black Sea via eDNA metabarcoding approach: From bacteria to marine mammals. Environ Int 135:105307 